\title{
Microbiology of primary acquired nasolacrimal duct obstruction: simple epiphora, acute dacryocystitis, and chronic dacryocystitis
}

This article was published in the following Dove Press journal:

Clinical Ophthalmology

22 February 2016

Number of times this article has been viewed

\author{
Kanograt Pornpanich' \\ Panitee Luemsamran' \\ Amornrut Leelaporn ${ }^{2}$ \\ Jiraporn Santisuk ${ }^{3}$ \\ Nattaporn Tesavibul' \\ Buntitar Lertsuwanroj' \\ Sumalee Vangveeravong' \\ 'Department of Ophthalmology, \\ ${ }^{2}$ Department of Microbiology, ${ }^{3}$ Eye \\ Surgery Unit, Faculty of Medicine, \\ Siriraj Hospital, Mahidol University, \\ Bangkok, Thailand
}

Purpose: The aim of this study was to determine the microbiology of primary acquired nasolacrimal duct obstruction (PANDO) and its antimicrobial susceptibilities.

Methods: Ninety-three patients (100 eyes) diagnosed with PANDO, categorized as acute, chronic dacryocystitis, or simple epiphora, were prospectively enrolled. Lacrimal sac contents were cultured for aerobic and anaerobic bacteria and fungi. Cultured organisms were identified, and antimicrobial susceptibility testing was performed for aerobic bacteria.

Results: Seventy-nine of the 100 samples were culture positive. One hundred twenty-seven organisms were isolated, and 29 different species were identified. Most microorganisms were Gram-positive bacteria (45 samples or $57.0 \%$ of all positive culture samples), whereas Gramnegative bacteria, anaerobic bacteria, and fungi were found in 39 (49.4\%), 24 (30.4\%), and four samples $(5.1 \%)$, respectively. The most frequently isolated group was coagulase-negative staphylococci (27.8\%), followed by nonspore-forming Gram-positive rods (anaerobe) (17.7\%) and Pseudomonas aeruginosa (15.2\%). Of the 100 samples, five, 45, and 50 samples were obtained from patients with acute dacryocystitis, chronic dacryocystitis, and simple epiphora, respectively. Subgroup analysis showed that Gram-negative organisms were isolated more frequently from the chronic dacryocystitis subgroup than from the simple epiphora subgroup $(P=0.012)$. Antimicrobial susceptibility testing demonstrated that ciprofloxacin was the most effective drug against all Gram-positive and Gram-negative organisms.

Conclusion: Patients with PANDO, with or without clinical signs of lacrimal infection, were culture positive. Gram-negative organisms were frequently isolated, which were different from previous studies. Ciprofloxacin was the most effective agent against all Gram-positive and Gram-negative organisms.

Keywords: microbiology, acquired nasolacrimal duct obstruction, simple epiphora, acute dacryocystitis, chronic dacryocystitis

\section{Introduction}

Primary acquired nasolacrimal duct obstruction (PANDO) describes a condition of nasolacrimal duct obstruction caused by inflammation or idiopathic fibrosis. ${ }^{1}$ Distal obstruction causes stagnation of lacrimal secretion, which may promote bacterial colonization and lacrimal sac infection. The clinical spectrum of nasolacrimal duct obstruction ranges from simple epiphora to acute or chronic dacryocystitis. Dacryocystitis occurs in acute and chronic forms. Acute dacryocystitis is the acute inflammation of lacrimal sac with localized erythema and tenderness of the skin overlying lacrimal sac area. Chronic dacryocystitis contains purulent or mucoid material in the lacrimal sac, which regurgitates on irrigation or pressure over sac area. Complications
Correspondence: Kanograt Pornpanich Department of Ophthalmology, Siriraj Hospital, Faculty of Medicine, Mahidol Universtiy, I4th floor Siamin building, 2 Wanglang Road, Bangkok 10700, Thailand

Tel +66814207042

Email jum484@yahoo.ca
Clinical Ophthalmology 2016:10 337-342

(c) (1) (2) ๑ 2016 Porrpanich et al. This work is published and licensed by Dove Medical Press Limited. The full terms of this license are available at https:/www.dovepress.com/terms.php cc) hereby accept the Terms. Non-commercial uses of the work are permitted without any further permisision from Dove Medical Press Limited, provided the work is properly attributed. For permission for commercial use of this work, please see paragraphs 4.2 and 5 of our Terms (https://www.dovepress. con/terms.php).
Dovepress

http://dx.doi.org/10.2147/OPTH.S100280

\section{7}

,


of dacryocystitis include fistula, corneal ulcer, and orbital cellulitis. There have been several previous studies regarding the microbiology of lacrimal duct obstruction causing chronic and acute dacryocystitis. ${ }^{2-4}$ The objective of this study was to describe the microbiology of nasolacrimal duct obstruction and to determine the susceptibility of the isolated organisms to common antimicrobial agents.

\section{Methods}

Ninety-three patients (100 eyes) diagnosed with PANDO between August 2008 and April 2011 were prospectively enrolled. All patients underwent a complete ophthalmic examination with lacrimal drainage system irrigation and intranasal examination. Lacrimal irrigation was performed to diagnose PANDO. Patients younger than 20 years, patients with canalicular obstruction, secondary nasolacrimal duct obstruction, ocular, and adnexal infection other than dacryocystitis (such as canaliculitis, hordeolum, blepharitis, conjunctivitis, keratitis, and endophthalmitis), and patients with a history of topical or systemic antibiotic usage within 1 week were excluded from the study. Written informed consent was obtained from all of the enrolled patients. Patients were categorized into acute dacryocystitis, chronic dacryocystitis, and simple epiphora subgroups based on the following clinical findings. Acute dacryocystitis was diagnosed in patients with tenderness, erythema, and swelling in the lacrimal sac area. Chronic dacryocystitis was diagnosed in patients with regurgitation of mucoid or mucopurulent discharge on the application of pressure over the lacrimal sac area or on the irrigation of lacrimal drainage system. Simple epiphora was diagnosed if the patient had PANDO without any clinical signs of infection of the lacrimal drainage system and no discharge on the application of pressure over the lacrimal sac area or on lacrimal irrigation.

All patients underwent either external or endoscopic dacryocystorhinostomy. Lacrimal sac contents of all 100 eyes were examined for the presence of bacteria and fungus using culture-based techniques. In patients with acute dacryocystitis who required incision and drainage, the contents of the lacrimal sac were directly collected using sterile cotton wool swabs during the incision and drainage procedure, taking care not to touch the skin and wound margin. In the remaining patients, the samples were intraoperatively collected using sterile technique prior to dacryocystorhinostomy by irrigating the lacrimal drainage system with sterile saline and aspirating the contents from the lacrimal sac via the punctum. Each sample was inoculated into 5\% sheep blood agar and incubated in an anaerobic jar. Samples were also inoculated into a second plate of 5\% sheep blood agar, a chocolate agar plate, and a thioglycollate broth and incubated aerobically. All inoculated media were incubated at $35^{\circ} \mathrm{C}$ for 3 days. Fungi were cultured on Sabouraud's agar, with and without chloramphenicol, at $25^{\circ} \mathrm{C}$ for 14 days. Gram staining of direct specimens was also performed. Bacteria and fungi were identified by standard phenotypic methods. Antimicrobial susceptibility of bacteria was tested by the disk diffusion method according to the Clinical and Laboratory Standards Institute guidelines. ${ }^{5}$ This study followed the tenets of the Declarations of Helsinki and was carried out with approval from the Siriraj Institutional Review Board.

\section{Statistical analysis}

Demographic data were presented by descriptive statistics. The categorical data were represented as the number and percentages. The continuous data were presented by mean and range. The chi-square test and Fisher's exact test were used to compare the differences in categorical data between subgroups. The $P$-value $<0.05$ was considered statistical significance for all statistical tests. Data analysis was performed using PASW Statistics 18.0.

\section{Results \\ Demographic data}

Cultures were obtained from 93 patients (100 eyes in total) diagnosed with PANDO. The mean age was 59.2 years (range 20-89 years), and the majority of patients were female $(81 / 93,87 \%)$. Fifty and 36 patients had right- and left-side infections, respectively, whereas seven patients had bilateral nasolacrimal duct obstruction. The mean duration of symptoms was 26.0 months (range 5 days to 22 years).

\section{Microbiology}

Among the100 samples, positive cultures were obtained from 79 samples $(79 \%)$. Of the culture-positive samples, 47 (59.5\%) yielded a single organism, while 32 (40.5\%) had two to five mixed organisms. In total, 127 organisms were isolated, and 29 different species were identified. The majority of microorganisms were Gram-positive bacteria (45 samples, $57.0 \%$ of all positive culture samples), whereas Gram-negative bacteria, anaerobic bacteria, and fungi were found in 39 (49.4\%), 24 (30.4\%), and four samples (5.1\%), respectively. The most commonly isolated microorganisms were coagulase-negative staphylococci (22 samples, 27.8\%). Nonspore-forming Gram-positive anaerobic rods, Pseudomonas aeruginosa, and Haemophilus influenzae were isolated from $14(17.7 \%), 12$ (15.2\%), and eleven samples (13.9\%), respectively. A summary of the microorganisms detected 
is presented in Table 1. The most frequent Gram-positive isolate was a group of coagulase-negative staphylococci, which represented $17.3 \%$ of all isolates and $43.1 \%$ of the Gram-positive group. The two most frequent Gram-negative isolates were $P$. aeruginosa and $H$. influenzae, which represented $9.4 \%$ and $8.7 \%$ of all organisms and $27.3 \%$ and $25.0 \%$ of the Gram-negative group, respectively. Nonspore-forming Gram-positive rods were the most frequent anaerobic bacteria and represented $50.0 \%$ of the anaerobe group and $11 \%$ of the total number of isolates.

\section{Subgroup analysis}

Patients were divided into three subgroups (acute dacryocystitis, chronic dacryocystitis, and simple epiphora). Of all 100 eyes, five, 45, and 50 had acute dacryocystitis, chronic dacryocystitis, and simple epiphora, respectively. The number of samples in the acute dacryocystitis subgroup was too small to provide adequate statistical power; therefore, we analyzed this subgroup separately and compared the distribution of microorganisms between the chronic dacryocystitis and simple epiphora subgroups only.

All samples in the acute dacryocystitis subgroup were culture positive. Gram-positive (three samples), Gram-negative (three samples), and anaerobic (three samples) bacteria were cultured, but no fungi were detected in this subgroup. The most commonly isolated bacterium was $H$. influenzae, which was isolated from two samples and represented $40 \%$ of the culture samples in the acute dacryocystitis subgroup.

The types of organisms isolated in each subgroup in the comparison between the simple epiphora and chronic dacryocystitis subgroups are presented in Table 2 and Figure 1. Gram-negative organisms in the chronic dacryocystitis

Table I Microbiology of primary acquired nasolacrimal duct obstruction

\begin{tabular}{|c|c|c|c|}
\hline & Number of organisms & $\begin{array}{l}\text { Percentage of all } \\
\text { organisms }(n=127)\end{array}$ & $\begin{array}{l}\text { Percentage of positive } \\
\text { culture samples }(n=79)\end{array}$ \\
\hline Gram positive & 51 & 40.2 & \\
\hline Coagulase-negative Staphylococcus spp. & 22 & 17.3 & 27.8 \\
\hline Staphylococcus aureus MSSA & 8 & 6.3 & 10.1 \\
\hline Streptococcus pneumoniae & 7 & 5.5 & 8.9 \\
\hline Streptococci B-hemolytic group F & I & 0.8 & 1.3 \\
\hline Streptococci alpha-hemolytic & 7 & 5.5 & 8.9 \\
\hline Corynebacterium spp. & 6 & 4.7 & 7.6 \\
\hline Gram negative & 44 & 34.6 & \\
\hline Pseudomonas aeruginosa & 12 & 9.4 & 15.2 \\
\hline Haemophilus influenzae & 11 & 8.7 & 13.9 \\
\hline Gram-negative rod NF & 4 & 3.1 & 5.1 \\
\hline Klebsiella pneumoniae & 2 & 1.6 & 2.5 \\
\hline Moraxella spp. & 2 & 1.6 & 2.5 \\
\hline Citrobacter koseri & 2 & 1.6 & 2.5 \\
\hline Proteus mirabilis & 2 & 1.6 & 2.5 \\
\hline Escherichia coli & 4 & 3.1 & 5.1 \\
\hline Enterobacter spp. & 2 & 1.6 & 2.5 \\
\hline Morganella morganii & I & 0.8 & 1.3 \\
\hline Stenotrophomonas maltophilia & I & 0.8 & 1.3 \\
\hline Neisseria spp. & 1 & 0.8 & 1.3 \\
\hline Anaerobe bacteria & 28 & 22.0 & \\
\hline Gram-positive rods, nonspore forming & 14 & 11.0 & 17.7 \\
\hline Propionibacterium acnes & 5 & 3.9 & 6.3 \\
\hline Porphyromonas spp. & 2 & 1.6 & 2.5 \\
\hline Veillonella spp. & 2 & 1.6 & 2.5 \\
\hline Fusobacterium nucleatum & 2 & 1.6 & 2.5 \\
\hline Clostridium spp. & I & 0.8 & 1.3 \\
\hline Peptostreptococcus spp. & I & 0.8 & 1.3 \\
\hline Prevotella melaniogenica & I & 0.8 & 1.3 \\
\hline Fungus & 4 & 3.1 & \\
\hline Yeast & 2 & 1.6 & 2.5 \\
\hline Candida parapsilosis & I & 0.8 & 1.3 \\
\hline Aspergillus flavus & 1 & 0.8 & 1.3 \\
\hline Total & 127 & 100.0 & 160.8 \\
\hline
\end{tabular}

Abbreviations: MSSA, methicillin-susceptible S. aureus; NF, nonfermentative Gram-negative rod. 
Table 2 Microbiology in the simple epiphora and chronic dacryocystitis subgroups

\begin{tabular}{llll}
\hline & Simple epiphora (n=50 samples) & Chronic dacryocystitis (n=45 samples) & P-value \\
\hline Growth & $37(74.0 \%)$ & $37(82.2 \%)$ & 0.335 \\
Gram-positive bacteria & $25(50.0 \%)$ & $17(37.8 \%)$ & 0.231 \\
Gram-negative bacteria & $13(26.0 \%)$ & $23(51.1 \%)$ & 0.012 \\
Anaerobe bacteria & $12(24.0 \%)$ & $9(20 \%)$ & 0.639 \\
Fungus & $2(4.0 \%)$ & $2(4.4 \%)$ & 1.000 \\
\hline
\end{tabular}

subgroup were isolated significantly more frequently than in the simple epiphora subgroup $(P=0.012)$.

\section{Antimicrobial susceptibility of bacteria}

Ciprofloxacin was the most effective agent (93.8\%) against all Gram-positive and Gram-negative organisms. The most effective agent against Gram-positive organisms was vancomycin ( $100 \%$ of isolates susceptible), followed by ciprofloxacin and chloramphenicol (93.3\%). All Staphylococcus aureus isolates were susceptible to oxacillin, ciprofloxacin, chloramphenicol, co-trimoxazole, clindamycin, and vancomycin. All Streptococcus pneumoniae isolates were susceptible to vancomycin, while $85.7 \%, 85.7 \%, 71.4 \%$, and $28.6 \%$ of these isolates were susceptible to ciprofloxacin, chloramphenicol, penicillin, and co-trimoxazole, respectively. All Gram-negative bacteria were susceptible to ceftazidime, and $93.9 \%$ were susceptible to ciprofloxacin. All $P$. aeruginosa isolates were susceptible to ceftazidime, ciprofloxacin, gentamicin, and meropenem. All H. influenzae isolates were susceptible to ceftazidime, chloramphenicol, and ciprofloxacin, whereas $90.9 \%$ were susceptible to ampicillin and amoxicillin/clavulanate, and 54.5\% were susceptible to co-trimoxazole.

\section{Discussion}

PANDO affects women more frequently than men, with a $3: 1$ female preponderance. ${ }^{6}$ In this study, 81 patients were female and 12 were male (6.7:1). Measurement of the bony nasolacrimal duct system has revealed that women have significantly smaller lower nasolacrimal fossa and middle nasolacrimal ducts, which might explain the higher prevalence of PANDO in women. ${ }^{7}$

Sample collection techniques vary between published studies, which might influence the levels of overall culture positivity. Hartikainen et al collected material refluxed through the lacrimal punctum, or by wiping a broth-moistened swab across the lower conjunctival cul-de-sac, and reported positive cultures in $84 \%$ of 127 samples. $^{3}$ DeAngelis et al analyzed the posterior lacrimal flap and found only $41.7 \%$ of the 132 samples were culture positive. ${ }^{4}$ In the present study,

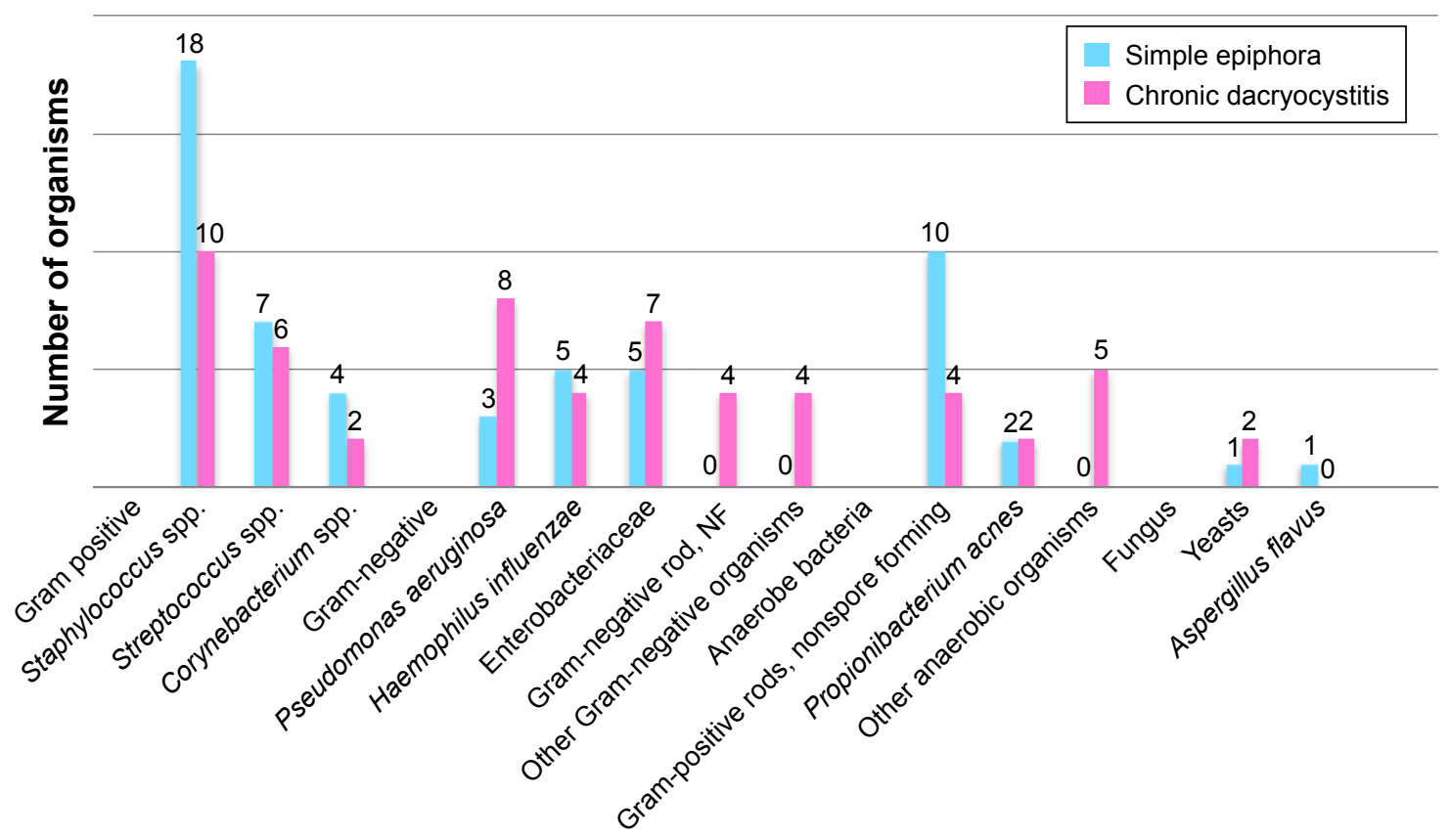

Figure I Distribution of organisms in the simple epiphora and chronic dacryocystitis subgroups. Abbreviation: NF, nonfermentative Gram-negative rod. 
$79 \%$ of the samples were culture positive. These samples were obtained directly from the lacrimal sac through the irrigating syringe without a lid, or conjunctival contamination under sterile surgical technique in the simple epiphora and chronic dacryocystitis subgroups. Five samples in the acute dacryocystitis subgroup were obtained by using a sterile cotton swab to collect content during the incision and drainage procedure.

The microbiology of lacrimal duct obstruction has been previously studied. DeAngelis et al reported that $78.5 \%$ and $21.5 \%$ of the organisms from 132 samples were Grampositive and Gram-negative bacteria, respectively, and $76.5 \%$ of the Gram-positive bacteria were staphylococci. ${ }^{4}$ Hartikainen et al found that $69 \%$ and $17 \%$ of all organisms isolated from 127 samples were Gram-positive and Gramnegative bacteria, respectively and that the most frequently cultured Gram-positive and Gram-negative species were Staphylococcus epidermidis and H. influenzae, respectively. ${ }^{3}$ In this study, although Gram-positive bacteria were the most common microorganisms ( $40.2 \%$ of all organisms), Gram-negative bacteria were isolated in almost equal proportions (34.6\%), which is in agreement with the study of Pinar-Sueiro et al who found $49.1 \%$ of Gram-positive and $43.9 \%$ of Gram-negative bacteria. ${ }^{8}$ These findings may show an increasing trend toward Gram-negative bacteria in nasolacrimal duct obstruction. However, it may reflect our geographic environment.

Patients in this study were clinically categorized into three subgroups: simple epiphora, chronic dacryocystitis, and acute dacryocystitis. All samples in the acute dacryocystitis subgroup were culture positive; however, the sample size was too small (five samples) for accurate statistical analysis. There was no statistically significant difference in the proportion of positive cultures obtained from the simple epiphora (74\%) and chronic dacryocystitis subgroups $(82.2 \%)$. This is consistent with the report of DeAngelis et al, which showed that the presence of a positive culture result was independent of a history of dacryocystitis or the presence of a mucocele. ${ }^{4}$ Owji and Khalili also reported that the mean colony count of microbial organisms was significantly higher in lacrimal sac and conjunctival culture of the obstructed side than the normal side. Therefore, this study confirms the importance of routine preoperative irrigation before intraocular surgery to avoid potentially pathogenic bacteria. ${ }^{9}$ Interestingly, in this study, we demonstrated a predominance of Gram-negative bacteria in the chronic dacryocystitis subgroup ( $46.6 \%$ of isolates), in contrast to the previous studies of chronic dacryocystitis, which showed that most microorganisms were Gram-positive bacteria. ${ }^{2,10-13}$ However, Briscoe et al demonstrated a higher incidence of Gram-negative bacteria, particularly Pseudomonas, in patients with purulent dacryocystitis. ${ }^{14}$ In this study, the prevalence of Gram-negative organisms was significantly higher in the chronic dacryocystitis subgroup than in the simple epiphora subgroup $(P=0.012)$. This result is consistent with the studies that have been described by Hartikainen et al and Amin et al., ${ }^{3,15}$ Therefore, antimicrobial drugs against Gram-positive and Gram-negative bacteria should be administered in chronic dacryocystitis.

In this study, anaerobic bacteria were found in all subgroups ( $22 \%$ of all isolates) and were represented mostly by nonspore-forming Gram-positive rods and Propionibacterium acnes. Anaerobic bacteria were present in 13\%-19\% of samples in previous studies, and Propionibacterium species were predominant. ${ }^{3,13}$ In contrast, Blicker and Buffam did not detect any anaerobic bacteria in patients with chronic dacryocystitis. ${ }^{16}$

All Gram-positive bacteria were sensitive to vancomycin, and $93.3 \%$ were sensitive to ciprofloxacin and chloramphenicol. In contrast, all Gram-negative bacteria were sensitive to ceftazidime, and $93.9 \%$ were sensitive to ciprofloxacin. Thus, ciprofloxacin was the most effective agent (93.8\%) against both Gram-positive and Gram-negative bacteria. These findings suggest that ciprofloxacin was effective in vitro against both Gram-positive and Gram-negative bacteria in this study and may be an initial treatment for chronic dacryocystitis because of its relatively high activity for most commonly found Gram-positive and Gram-negative bacteria.

\section{Conclusion}

Most patients with PANDO, with or without clinical signs of lacrimal infection, were culture positive. Therefore, routine preoperative irrigation before intraocular surgery is recommended. The proportion of Gram-negative organisms was high in patients with nasolacrimal duct obstruction, especially in the chronic dacryocystitis subgroup; this may show an increasing trend toward Gram-negative bacteria in nasolacrimal duct obstruction or reflect our geographic environment.

\section{Acknowledgment}

This study was supported by Siriraj Research Development Fund, Thailand (managed by Routine to Research).

\section{Disclosure}

The authors report no conflicts of interest in this work. The authors alone are responsible for the content and writing of the article. 


\section{References}

1. Linberg JV, McCormick SA. Primary acquired nasolacrimal duct obstruction. A clinicopathologic report and biopsy technique. Ophthalmology. 1986;93(8):1055-1063.

2. Badhu BP, Karki BS, Khanal B, Dulal S, Das H. Microbiological patterns of chronic dacryocystitis. Ophthalmology. 2006;113(12):e1-e2.

3. Hartikainen J, Lehtonen OP, Saari KM. Bacteriology of lacrimal duct obstruction in adults. Br J Ophthalmol. 1997;81(1):37-40.

4. DeAngelis D, Hurwitz J, Mazzulli T. The role of bacteriologic infection in the etiology of nasolacrimal duct obstruction. Can J Ophthalmol. 2001; 36(3):134-139.

5. Clinical and Laboratory Standards Institute (CLSI). Performance Standards for Antimicrobial Susceptibility Testing: Twenty-First Informational Supplement. PA: CLSI; 2007. CLSI Document M100-S17.

6. Linberg JV. Disorders of the lower excretory system. In: Milder B, Weil BA, editors. The Lacrimal System. New York, NY: Appleton-Century-Crafts; 1983:9-22.

7. Groessl SA, Sires BS, Lemke BN. An anatomical basis for primary acquired nasolacrimal duct obstruction. Arch Ophthalmol. 1997;115(1): 71-74.

8. Pinar-Sueiro S, Fernández-Hermida RV, Gibelalde A, Martínez-Indart L. Study on the effectiveness of antibiotic prophylaxis in external dacryocystorhinostomy: a review of 697 cases. Ophthal Plast Reconstr Surg. 2010;26(6):467-472.
9. Owji N, Khalili MR. Normalization of conjunctival flora after dacryocystorhinostomy. Ophthal Plast Reconstr Surg. 2009;25(2):136-138.

10. Mandal R, Banerjee AR, Biswas MC, Mondal A, Kundu PK, Sasmal NK. Clinicobacteriological study of chronic dacryocystitis in adults. J Indian Med Assoc. 2008;106(5):296-298.

11. Das JK, Deka AC, Kuri GC, Bhattacharjee K, Das D, Gogoi K. Bacteriology of chronic dacryocystitis in adult population of northeast India. Orbit. 2008;27(4):243-247.

12. Sun X, Liang Q, Luo S, Wang Z, Li R, Jin X. Microbiological analysis of chronic dacryocystitis. Ophthalmic Physiol Opt. 2005;25(3): 261-263.

13. Chaudhry IA, Shamsi FA, Al-Rashed W. Bacteriology of chronic dacryocystitis in a tertiary eye care center. Ophthal Plast Reconstr Surg. 2005;21(3):207-210.

14. Briscoe D, Rubowitz A, Assia E. Changing bacterial isolates and antibiotic sensitivities of purulent dacryocystitis. Orbit. 2005;24(1):29-32.

15. Amin RM, Hussein FA, Idriss HF, Hanafy NF, Abdallah DM. Pathological, immunohistochemical and microbiological analysis of lacrimal sac biopsies in patients with chronic dacryocystitis. Int J Ophthalmol. 2013;6(6):817-826.

16. Blicker JA, Buffam FV. Lacrimal sac, conjunctival, and nasal culture results in dacryocystorhinostomy patients. Ophthal Plast Reconstr Surg. 1993;9(1):43-46.
Clinical Ophthalmology

\section{Publish your work in this journal}

Clinical Ophthalmology is an international, peer-reviewed journal covering all subspecialties within ophthalmology. Key topics include: Optometry; Visual science; Pharmacology and drug therapy in eye diseases; Basic Sciences; Primary and Secondary eye care; Patient Safety and Quality of Care Improvements. This journal is indexed on

\section{Dovepress}

PubMed Central and CAS, and is the official journal of The Society of Clinical Ophthalmology (SCO). The manuscript management system is completely online and includes a very quick and fair peer-review system, which is all easy to use. Visit http://www.dovepress.com/ testimonials.php to read real quotes from published authors. 